\title{
Reproductive Development of the Christmas Rose (Helleborus niger L.): The Role of Plant Hormones
}

\author{
Branka Salopek-Sondi \\ Department of Molecular Biology, Ruđer Bošković Institute, Bijenička cesta 54, Zagreb, Croatia \\ (E-mail: salopek@irb.hr)
}

RECEIVED DECEMBER 30, 2010; REVISED MARCH 4, 2011; ACCEPTED MARCH 10, 2011

\begin{abstract}
Christmas rose (Helleborus niger L.), a native perennial of southeastern Europe, is characterized by an interesting phenomenon in the world of flowering plants: after fertilization perianth becomes green, photosyntheticaly active, and persists during fruit development. Removal of the reproductive organs (anthers and carpels) affects the elongation and vascular anatomy of flower stalk, prevents complete perianth greening, and promotes perianth senescence. Endogenous plant hormones auxins, gibberellins and cytokinins, identified and quantified in floral and fruit tissues, are shown to regulate reproductive development. Dynamics of these signaling molecules are summarized and their potential role in coordination of floral organ development are discussed.(doi: 10.5562/cca1820)
\end{abstract}

Keywords: Helleborus niger L., reproductive development, auxin, cytokinin, gibberrelin, LC-MS/MS analysis.

\section{INTRODUCTION}

Plant reproductive development, considering flowering and the production of a viable seeds as final result, is a complex, and well regulated process dependent on a number of biotic and abiotic factors. It can be separated into five main phases: (1) development of reproductive organs (pre-anthesis), (2) flowering (anthesis) at which pollination and fertilization occur, (3) fruit growth and development (post-anthesis), and (4) fruit maturation. Plant hormones are endogenous signaling compounds highly involved in the regulation of each of these steps. ${ }^{1-5}$ Pollination and fertilization are events crucial for the fate of, usually attractive flowers. The most basic function of showy flower perianth is an attraction of pollinators. Thus, shortly after pollination, colorful perianth of the most flowers enter the process of senescence (involving changes in pigmentation, shedding or wilting), and finally abscission. ${ }^{6,7}$ This highly regulated process involves complex structural, biochemical and molecular changes in plant cells, and, it is in many cases considered as a one type of programmed cell death. $^{8-11}$

Exceptionally, in some species, pollination and/or the presence of developing fruit increase the life span of the perianth which then tends to turn green (or darker green) contributing to the photosynthetic assi- milation. The number of published studies deals with orchids, ${ }^{7}$ araceans Spathiphyllum wallisii Regel, ${ }^{12}$ Zantedeschia aethiopica Spreng. ${ }^{13,14}$ and Z. elliotiana Engl., ${ }^{15}$ as well the dicots Chrysosplenium alternifolium L., C. oppositifolium L., ${ }^{16}$ and Nuphar luteum Sibth. et Sm. ${ }^{15}$ In all of these species, unpollinated or depistillated flowers or inflorescences entered the program of senescence much earlier than their pollinated counterparts.

Reproductive development of Christmas rose (Helleborus niger L.) is one impressive example of this phenomenon. ${ }^{1-19}$ Herein, we describe reproductive development of the Christmas rose, give overview of the endogenous plant hormones profile, and discuss on their possible roles in triggering and mediating of an uncommon morphological changes of flowers.

\section{REPRODUCTIVE DEVELOPMENT OF THE CHRISTMAS ROSE (HELLEBORUS NIGER L.)}

A Christmas rose (H. niger) belongs to the genus Helleborus (family Ranunculaceae) which comprises about 20 perennial species with large, attractive flowers in various shades of purple, green, and white. ${ }^{20} \mathrm{~A}$ detailed botanical description can be found elsewhere. $^{19,21,22}$ The plants used in our experiments were

\footnotetext{
$\dagger$ This article belongs to the Special Issue Chemistry of Living Systems devoted to the intersection of chemistry with life.
} 


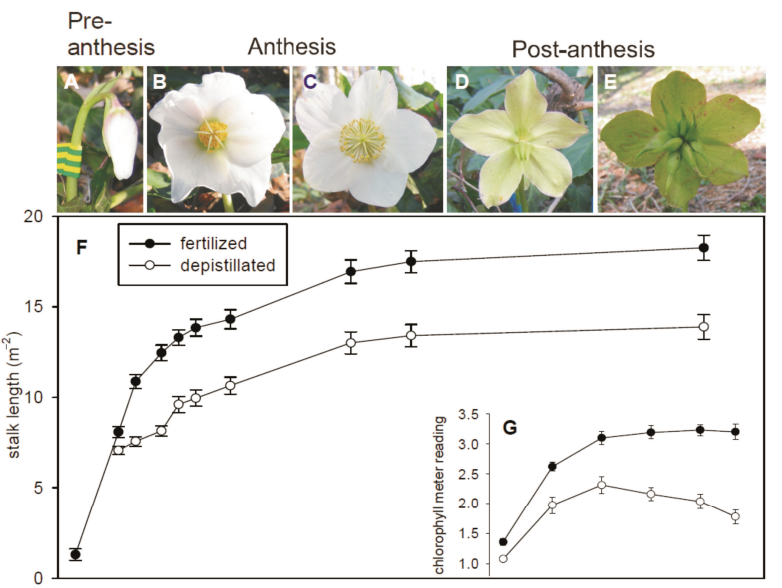

Figure 1. Representative developmental stages of the Christmas rose flower (Helleborus niger L.): bud stage at preanthesis (A), "Female" (B) and "Male" (C) stages at anthesis, and "Light green" (D), and "Green" (E) stages at postanthesis. Elongation of flower stalk $\left(\mathrm{m}^{-2}\right)(\mathrm{F})$, and chlorophyll accumulation in perianth during post-anthesis (measured by chlorophyll meter) $(G)$ were monitored in fertilized control (closed circles), and depistillated flowers (open circles). Data are arithmetic mean \pm SE ( $n=20$ to 25$)$.

collected at two locations through several growth seasons: habitat 1 was a natural mountain forest at Gorski kotar, Croatia (altitude: $800 \mathrm{~m}$ ), and habitat 2 was a woodlot at the "Fran Kušan" Botanical Garden of the Faculty of Pharmacy and Biochemistry of the University of Zagreb.

The Christmas rose may produce flowers from early winter up until late spring. In mild winters, the flowers may indeed appear at Christmas time and maintain until April or May. The seeds generally mature by May. Floral longevity strongly depends on the temperature fluctuations as reported for other Hellebores species. ${ }^{23}$ Since the developmental stages could not be defined on an absolute time scale, several developmental stages were described according to morphological parameters, such as the lengths and weights of the sepals and fruit clusters, intensity of sepal greening, and the length of the flower stalk. ${ }^{19}$ Figure 1 shows representative stages of $H$. niger flower development: bud stage at pre-anthesis (A), female (B) and male (C) stages at anthesis, light green (D) and green stages (E) at postanthesis.

It is shown that this species is generally credited with pure white flowers. When the bud appeared over ground (pre-anthesis), it was already 10-15 mm long, and its size thus increased only about twice before unfolding (Figure 1A). Simultaneously, the flower stalk grew at a much faster rate to attain its final length (approximately $20-25 \mathrm{~cm}$ ) shortly after anthesis (Figure $1 \mathrm{~F})$. The sepals appeared to elongate at bud opening (anthesis), but there was little expansion afterwards. The proterogynous flowers first passed through their female phase (Figure 1B) during which the stigmata were receptive, the immature anthers were arranged in a ring at the base of the cluster of carpels. The male phase (Figure 1C) began with the elongation of the filaments, and ended with their abortion. After pollination (postanthesis), the sepals first turned yellowish-greenish (Figure 1D), then green (Figure 1E), and maintained this color until shortly before seed shedding. They becomes photosynthetically active, leaf like organs. Fruit consists of pericarp inside which seeds grow. Fruit length increased about threefold, while fresh weight (FW) accumulation of the fruit increased 6 to 7 fold until the last stage of development. In Helleborus seeds, both endosperm growth and embryo differentiation start around the time when the sepals begin turning green. As long as the seeds are connected to the mother plant, embryo development does not progress beyond an early cotyledonary stage. ${ }^{24-26}$ After-ripening period of about three months at room temperature followed by two months at $+4{ }^{\circ} \mathrm{C}$ are required for the embryos to differentiate into cotyledons and hypocotyl-radicle, thus enabling the seeds to germinate.

In addition to interesting post-anthesis transformation of flower following fertilization, the Christmas rose is well-suited for experimental work on flower biology due to size and life span of its flowers. All elements of their large flowers are accessible, while single flower, is in many case, sufficient for hormone, pigment, and related biochemical analyses. The greening process in the perianth and elongation of flower stalk, are linked to the presence of developing fruit, which makes the fertilized Christmas rose flower an interesting model for studying developmental aspects of sink-source interactions.

\section{HOW IS THE FLORAL DEVELOPMENTAL PROGRAM OF THE CHRISTMAS ROSE CHANGED IF FERTILIZATION FAILED?}

The fate of white, attractive Christmas rose flowers are strongly influenced by fertilization and fruit development. ${ }^{17-19}$ As already mentioned, life cycle of an intact flowers are characterized by processes such as intensive flower stalk elongation at pre-anthesis and anthesis, flower opening and sepal growth at anthesis, and sepal greening at post-anthesis during which fruit was growing and developing (Figure 1). On the other side, flowers in which fertilization was prevented, naturally or experimentally by removing the anthers (unfertilized flowers), or exciding the entire reproductive organs (depistillated flowers), survive as long as fertilized counterparts but do not pass through entire developmental process. Impact of depistillation on the 
perianth and stalk development is the most evident on the greening process of sepals and the flower stalk elongation.

Greening process of Christmas rose sepals is connected with differentiation of chloroplasts from colorless plastids leucoplasts, and subsequent accumulation of photosynthetic pigment (chlorophylls and carotenoids). ${ }^{17}$ In the sepals of fertilized flowers chlorophyll accumulates gradually until the value of 3.5 monitored by chlorophyll meter (which correspondents to approximately $350 \mathrm{mg}$ per $\mathrm{g}$ of $\mathrm{FW}$ ) at stationary green stage phase (Figure 1G).

The greening process of sepals is significantly inhibited if developing fruits are missing. Chlorophyll accumulation in the sepals of depistillated flowers does never reach the level of fertilized ones. Thus, chlorophyll maximal level reaches about $70 \%$ of that measured in fertilized flower sepals (Figure 1G).

Furthermore, depistillated flowers enter the program of senescence earlier in comparison to fruitbearing counterparts what is firstly evident by visual observation. It was detected at ultrastructural level where gerontoplasts were shown to be predominant plastids in the sepal cells of depistillated flowers in comparison to typical, well developed chloroplasts present in the cells of fertilized flowers of the same age. ${ }^{17-19}$ At biochemical level, this thesis can be confirmed by several parameters such as decreased chlorophylls/carotenoids ratio, ${ }^{17}$ elevated accumulation of $\mathrm{H}_{2} \mathrm{O}_{2}$ and lower activities of an antioxidant enzymes in depistillated flowers in comparison to fertilized ones. ${ }^{27}$

The most prominent elongation of flower stalk occurs at pre-anthesis when its length increased up to ten fold (from 1 to $10 \mathrm{~cm}$ ) (Figure 1F). Thereafter, stalk elongated additionally about twice during anthesis and early post-anthesis period reaching, at stationary phase, approximately 20 to $25 \mathrm{~cm}$. In depistillated flowers, stalk growth was stunted through their lifespan and never reached the length of fruit-bearing flowers. Thus the flower stalk of depistillated flowers at the stationary phase reached $68 \%$ of the fertilized flower stalk. Similar effect of flower stalk growth inhibition upon bud decapitation or emasculation was observed in miniature Cymbidium orchid, ${ }^{28}$ tulip, and daffodil. ${ }^{29-31}$

Depistillation additionally impacts the vascular anatomy. In the stalk of fruit bearing flower the vascular tissue showed phloem and xylem fully developed with an interfascicular cambium layers well distinguished between them. Significant deposition of lignin and cellulose was observed in sclerenchyma surrounding vascular bundle. In contrast, vascular bundles found in the stalk of depistillated flowers are generally smaller, interfascicular cambium has been hardly noticed and the lignin deposition was significantly lower. ${ }^{27}$

\section{IMPORTANCE OF FLORAL PHOTOSYNTHESIS IN THE CHRISTMAS ROSE}

It has been already reported that floral photosynthesis in some species can provide a significant part of the carbon needed for reproduction. ${ }^{32}$ Green sepals of fruit bearing $H$. niger flowers are shown to be photosynthetic active being able to produce approximately $60 \mu \mathrm{mol}$ of oxygen per hour per g FW, which is one-half, and oneforth of production determined in young leaves, and mature leaves, respectively. ${ }^{21}$ Aschan and Pfanz ${ }^{32}$ determined electron transport rates (at the photon flux density of $600 \mu \mathrm{mol} \mathrm{m} \mathrm{m}^{-2} \mathrm{~s}^{-1}$ ) in green sepals of about 60 $\%$ of those in mature leaves. On the other side, photosynthetic efficacy of depistillated flower has been shown to follow the trend of chlorophyll accumulation, and found to accomplish about $30 \%$ of value determined in the sepals of fruit-bearing flower. ${ }^{27}$ Comparable, green sepals of Helleborus viridis contribute more than $60 \%$ of the whole-plant $\mathrm{CO}_{2}$ gain in early spring. ${ }^{33}$ Young inflorescences of the terrestrial orchid Spiranthes cernum achieved one-third of the leaf photosynthesis. ${ }^{34}$ Green spots on the white inner tepals of Snowdrop ( $\mathrm{Ga}$ lanthus nivalis L.), ${ }^{35}$ and white perigon tips of Leucojum vernum $\mathrm{L}^{36}$ achieved photosynthesis of about one-forth and one-third of that measured in the fully developed leaves, respectively.

The primary, an ecological role of green spots on the white perianth, and regreened parts of perianth during fruit development are mainly attraction of pollinators, and protection against herbivores, respectively. A second relevant function of green or regreen parts of perianth is proposed to be in performing an efficient photosynthesis and providing the flower and the developing seeds with assimilates.

In the Christmas rose, like other helebore species, the overwintering leaves are often pressed to the ground by snow and covered with debris, and naturally die back in early winter when fertilization and young fruits occured. New generation of leaves emerges later in spring during fruit developing and ripening, and fully expand after seed maturity. ${ }^{37}$ Green sepals achive maximum of photosynthetic activity at that time. Apart from the stores in the roots, the green perianth thus represents the most reliable source of assimilates for the developing seeds in this and other species of Helleborus. Herrera ${ }^{38}$ approved this theory by showing the positive corelation between calyx size and seed mass in green flowering Helleborus foetidus: he found an approximately $10 \%$ decrease in final seed weight (but no effect on seed number) when he removed the sepals right after pollination. In the most of flowers of $H$. niger deprived of their sepals, the fruit aborted before maturity. In the single recorded case, in which claster of the fruit remained 
viable, their lenght only reached one-half, while their overall fresh weight one-third of the values observed for intact fertilized flowers. ${ }^{18}$

\section{PLANT HORMONES - REGULATORS OF THE REPRODUCTIVE DEVELOPMENT OF CHRISTMAS ROSE}

Since the morphological changes of flower organs are influenced by fertilization and fruit development, an intriguing question is the following: how do these fruits communicate with other floral parts and mediate certain changes observed in the Christmas rose during reproductive period? Fruit tissues are known to be rich source of plant hormones, the small signaling molecules that generally coordinate and mediate plant development. ${ }^{1,2,39}$ According to historically established classification there are five main groups of plant hormones: auxins, cytokinins, gibberellins, abscisic acid (ABA), and gas ethylene. In addition, brassinosteroids, salicylic acid (SA) and jasmonates are also shown to act as endogenous signaling molecules. ${ }^{2}$

In order to test the potential role of different plant hormones in the Christmas rose flower development, our first approach accomplished a treatment of depistillated flowers with several representatives of plant hormones auxins [indole-3-acetic acid (IAA), 4chloroindole-3-acetic acid (4-Cl-IAA)], cytokinins [ $N^{6}$-benzyladenine (BA), trans-zeatin (Z), trans-zeatin riboside (ZR), dihydrozeatin (DZ), dihydrozeatin riboside (DZR), $N^{6}-\left(\Delta^{2}\right.$-isopentenyl)adenine (iP), $N^{6}-\left(\Delta^{2}-\right.$ isopentenyl)adenine riboside (iPR)], and gibberellins $\left[\mathrm{GA}_{3}, \mathrm{GA}_{4}, \mathrm{GA}_{7}\right]$. The representatives of these three groups of plant hormones are shown in Figure 2. They were applied in lanoline paste, in concentrations ranging from $10^{-5}$ to $10^{-2} \mathrm{~mol} \mathrm{dm}^{-3}$, to the inner surfaces of the sepals of depistillated flowers at the anthesis. Results were monitoring six to eight weeks upon treatment when fruit bearing counterparts reached the "green phase" of development. The effect of hormone application on the depistillated flowers was clear-cut: all cytokinins stimulated sepal greening, the auxins had no such effect on chlorophyll accumulation but promoted flower stalk elongation while gibberellins were participated in both, sepal greening and stalk elongation. ${ }^{18}$ At the cellular level, hormone treatment affected both the abundance of chloroplasts and their ultrastructure. Cytokinin- and gibberellin-treated sepals contained comparable number of chloroplast as fruit-bearing flowers of the same age with a typical ultrastructure: dense stroma with numerous ribosomes, and well developed grana and stroma tylakoids. On the other side, untreated and auxin-treated sepals of depistillated flowers contained significantly lower number of mostly degenerated chloroplasts with
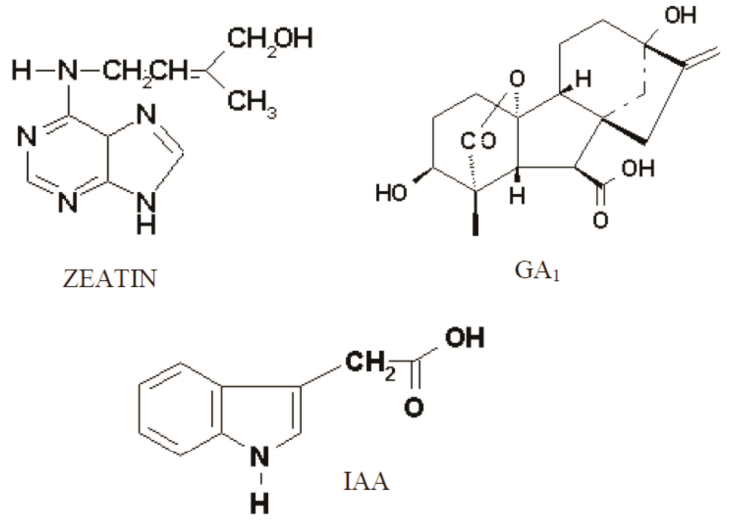

Figure 2. Plant hormones representatives: cytokinin zeatin $(\mathrm{Z})$, gibberellin $\mathrm{A}_{1}\left(\mathrm{GA}_{1}\right)$, and auxin indole-3-acetic-acid (IAA).

relatively transparent stroma containing spare ribosomes, and many large plastoglobules while thylakoids were few in number and assembled into atypical grana. Cytokinins have long been known as hormones preventing the chlorophyll degradation, or to increase its accumulation. Many studies showed that cytokinins are involved in the prevention the plant tissue of the senescence, particularly the photosynthesis apparatus. $^{40}$

In addition, cytokinins preserve the chloroplast integrity by increasing activity of antioxidant enzymes (catalase and ascorbate peroxidase) and decreasing the level of $\mathrm{H}_{2} \mathrm{O}_{2}$ and reactive oxygen species (ROS). ${ }^{41}$ The role of gibberellins appears to overlap with that of cytokinins; they reduce chlorophyll degradation in senescing lettuce leaves, ${ }^{42}$ in Alstroemeria shoots, ${ }^{43}$ and in ripening citrus fruits. ${ }^{44}$ Furthermore, both hormones increased the expression of NADPH-protochlorophyllide oxidoreductase, an enzyme of chlorophyll biosynthesis. ${ }^{45}$ In a number of species, auxins and gibberellins have been shown to regulate the flower stalk development and elongation. The removal of the flower or floral organs resulted in inhibition of the floral stalk elongation. ${ }^{28}$ Treatments of emasculated or decapitated flowers with auxins, ${ }^{28-31}$ as well as treatments of isolated stalk explants ${ }^{46}$ led to the conclusion that these plant hormones originated in anthers, gynoecium or developing fruit are mostly responsible for stalk elongation. A complex interplay of auxins and gibberellins in flower stalk elongation has, for instance, been studied in tulip, ${ }^{47}$ and barley. ${ }^{48}$

The application of plant hormones cytokinins, gibberellins, and auxins to the sepals of depistillated flowers mimicked some of the correlative signals released by the fruit developing in intact flowers. Thus, the profile and dynamics of endogenous hormones were of particular interest as a next step in the investigation of their role in floral developmental program. 


\section{Endogenous Cytokinins}

Endogenous cytokinins are $N^{6}$-substituted adenine compounds (Figure 2) which exist in the plant cell as mixtures of free bases, nucleosides as well as mono-, di-, and tri-nucleotides in apparent equilibrium. Two types of cytokinins according to side chain are recognized, an isoprenoid and an aromatic cytokinins. ${ }^{2,49}$ All forms of cytokinins may be reversible or irreversible conjugated with sugars, and amino acids, both, at the adenine moiety or the side chain. ${ }^{50}$ The adenine ring can be glucosylated at the $N^{3}-, N^{7}$ - and $N^{9}$-position. Conjugation of cytokinins involves also $O$-glycosylation, and $O$ acetylation at the hydroxyl group of the side chains of cytokinins. Free-base cytokinins are generally accepted as an active forms, nucleosides, because of their abundance in the vascular tissues, are suggested to be translocation forms, while sugar conjugates are the storage and inactivated cytokinins forms. ${ }^{2,50}$

Cytokinin analyses in the floral tissues have been done by LC-MS/MS. ${ }^{25}$ A protocol based on immunochromatography and liquid chromatography-mass spectrometry revealed the presence of the free bases $(Z, D Z, i P)$, their ribosides, and the corresponding $O$-glucosides and riboside monophosphates, while 9-glucosides were only detected in some developmental stages, in a very small amounts. Cytokinin quantification was accomplished by isotope dilution, using deuterated internal standards.

The overall cytokinin levels increased significantly in the fruit during early development ("Light green" to "Green" stage), and then continued with accumulation until the last investigated stage (Figure 3A). Cytokinin conjugates accumulate in accordance with the free bases increase. Details about distribution of particular cytokinin species during flower and fruit development are described earlier. ${ }^{19,25}$ In brief, riboside monophosphates (iPRMP, ZRMP, DZRMP) peaked first, followed by the ribosides ( $Z R$ and $D Z R$ ), while the free bases ( $Z$ and $\mathrm{DHZ}$ ) were the most abundant in the last developmental stage analyzed ("Almost ripe" stage, 2-3 weeks before seed ripening). At anthesis, DZ-type cytokinins were slightly more abundant than their zeatin analogs, but, during post-anthesis, this proportion was inverted, with $\mathrm{Z}$ and derivatives attaining up to seven times higher concentrations. At the last developmental stage (almost ripe fruit), cytokinins were mostly localized in seeds $(80 \%)$ in comparison to peicarp $(20 \%)$. Zeatin type cytokinins were first isolated from immature corn seeds, ${ }^{51}$ and appear to be abundant in developing fruits and seeds of other plant species, such as kiwi fruit, ${ }^{52}$ cereal grains, ${ }^{53,54}$ chickpea, ${ }^{55}$ and white lupine. ${ }^{56}$ In these species cytokinin levels rise dramatically after fertilization, and then, drop abruptly during the late ripening stage. This cytokinin peak is usually correlated with cell division rates in the endosperm. ${ }^{54,57}$ In contrast, cytokinins were high in $\mathrm{Hel}$ leborus seeds until the end of development. As men-
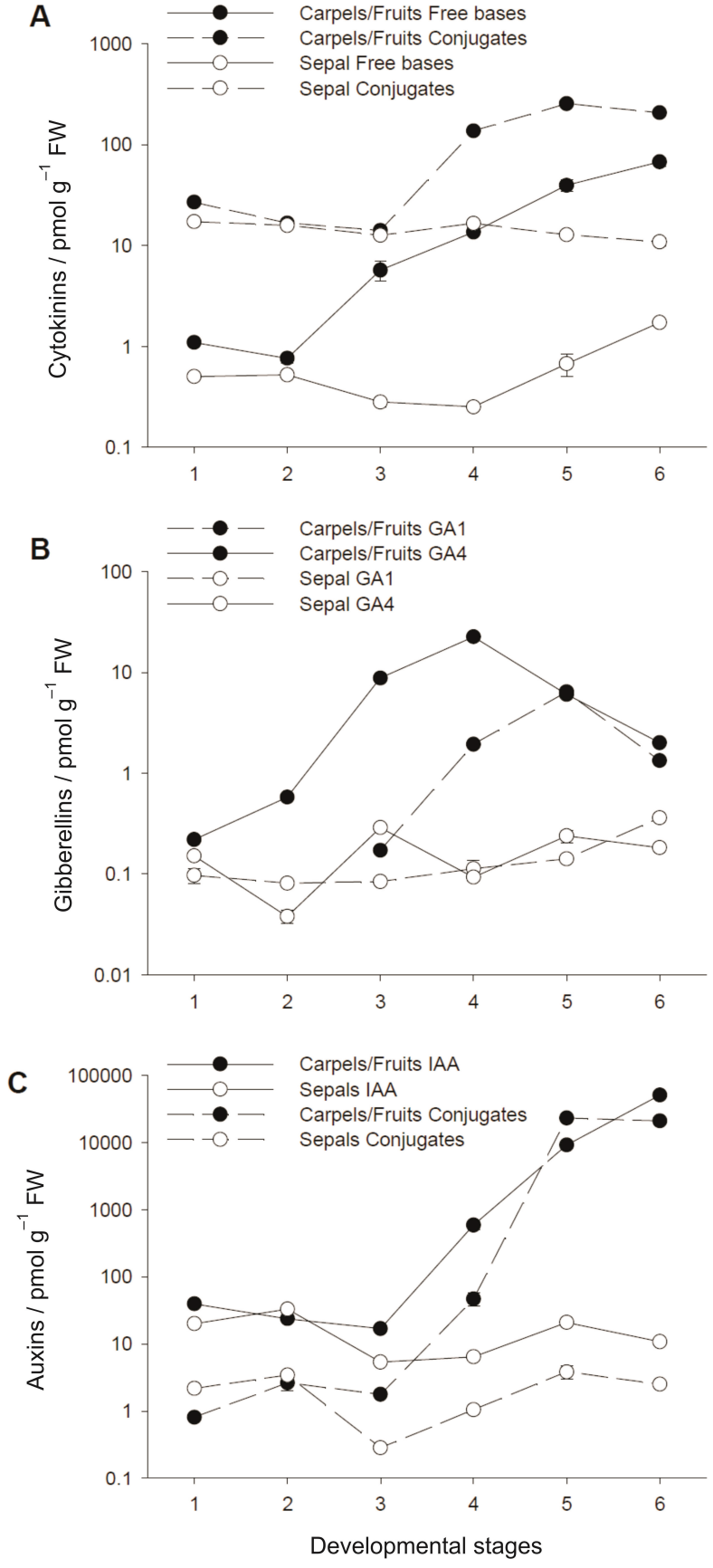

Figure 3. Endogenous plant hormones cytokinins (A), gibberellins (B), and auxins (C) analyzed in the Christmas rose carpels/fruits (closed circles) and perianth (open circles) during anthesis (Female, 1; and Male, 2), and post-anthesis (Light green, 3; Advanced green, 4; Green, 5; and Almost ripe, 6).

tioned earlier, embryo development in the Christmas rose does not progress beyond an early cotyledonary stage, as long as the seeds are attached to the mother plant. ${ }^{24-26}$ Thus, the constantly high cytokinin levels throughout fruit maturation, are probably required for embryo differentiation up to the cotyledonary stage which occur finally in the postripening period. ${ }^{58,59}$ 
While overall fruit cytokinins increased precipitously, their pooled concentrations in the sepals did not pass through such a significant changes (Figure 3A). Free cytokinins elevated during two last stages of development when intensive photosynthesis occurs in sepal tissue. Only iPRMP peaked transiently, when perianth greening was initiated. ${ }^{25}$ The changes were less pronounced than in the developing fruit, but occurred in the same time frame. To verify the effect of developing seeds on cytokinin levels in the sepals, depistillated flowers were also analyzed at the green developmental stage. ${ }^{25}$ As can be seen, the overall cytokinins level was significantly lower in the sepals of deseeded flowers than in the sepals of fruit-bearing flowers of the same physiological age (Figure 4A). In addition, ribotides (particularly iPRMP) were not detected. The perianth of seedless flowers also weighed less and did not pass through a complete greening process. It may be concluded that iPRMP is the cytokinin transported from the fruit to the perianth to induce the greening response. Endogenous cytokinin analysis in combination with results of exogenous treatments indicates that cytokinins play role in the normal life cycle of the perianth including the greening response following fertilization.

\section{Endogenous Gibberellins}

Gibberellins (GAs) are tetracyclic diterpenoid acids (Figure 2) synthesized from acetyl CoA via the mevalonic acid pathway. There are two classes based on the presence of 19 or 20 carbons organized into either four or five rings. The 19-carbon forms are, in general, the biologically active gibberellins. There are currently 136 GAs identified from plants, fungi and bacteria. They are named by numbers $\left(\mathrm{GA}_{1}, \mathrm{GA}_{2}\right.$ etc.) in order to their identification (http://www.plant-hormones.info/gibberellins.htm).

Among 136 GAs, only a few are identified as an active hormones $\left(\mathrm{GA}_{1}, \mathrm{GA}_{3}, \mathrm{GA}_{4}, \mathrm{GA}_{5}, \mathrm{GA}_{6}\right.$, and $\left.\mathrm{GA}_{7}\right)$, while others presents precursors and catabolites in the GA metabolic pathway. ${ }^{2}$ GAs are believed to be synthesized in young tissues of the shoot and also the developing seed. Seed originated GAs are also likely to be involved in the coordination of fruit and perianth development. ${ }^{1,4,60}$

Endogenous gibberellin levels in the Christmas rose were determined by LC-MS/MS [consisting of a quadrupole/time of flight tandem mass spectrometer and an Acquity Ultra Performance Liquid Chromatograph equipped with a reversed-phase column] using ${ }^{2} \mathrm{H}_{2}$ labeled GAs as internal standards according to Varbanova et al. ${ }^{61}$ Two physiologically active gibberellins, $\mathrm{GA}_{1}$ and $\mathrm{GA}_{4}$, and a number of their precursors and catabolites were identified and quantified in floral and fruit tissue during development. ${ }^{26}$

Dynamic of bioactive gibberellins $\left(\mathrm{GA}_{1}+\mathrm{GA}_{4}\right)$ are displayed on Figure 3B. As can be seen, the level of total
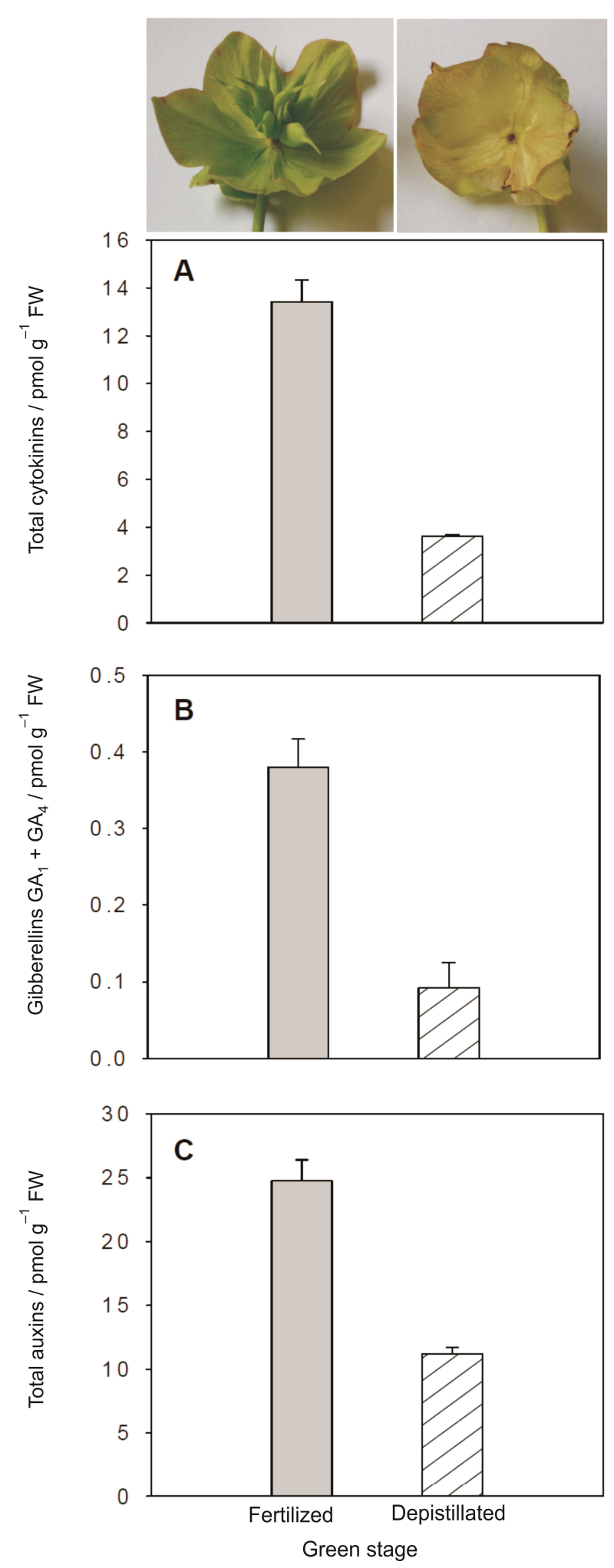

Figure 4. Comparison of endogenous hormones cytokinins (A), gibberellins (B), and auxin (C) in the sepals of fertilized and depistillated flowers.

bioactive GAs starts increasing after fertilization ("Male" stage) and continuing during early fruit devel- 
opment. Two bioactive GAs are differently distributed during fruit development: $\mathrm{GA}_{4}$ peaked during embryo development and $\mathrm{GA}_{1}$ during the subsequent period of rapid nutrient accumulation. The $\mathrm{GA}_{4}$ level in developing fruit rose its peak when sepal greening was intensive ("Light green" to "Green" stage), at a concentration about 100 times above that in the pistils in their "Female" phase. This pattern overlaps with embryo and endosperm differentiation which passes through its initial stages during the "Light Green" phase to yield, at seed maturation, a miniature embryo in its early cotyledonary stage, enclosed in a just slightly larger endosperm, all enveloped by a prominent perisperm as the major storage tissue. Bioactive gibberellins are required for embryo growth and seed development and generally accumulate during these processes. ${ }^{4,62}$ Particularly detailed in vitro studies in carrot and anise ${ }^{63,64}$ indicated increased $\mathrm{GA}_{4}$ biosynthesis during the differentiation of somatic embryos. The pericarps contained about six times more $\mathrm{GA}_{1}$ than the seeds, while the $\mathrm{GA}_{4}$-concentrations were equivalent in both tissues. Gibberellins' concentrations in the sepals ranged from 2 to 50 times below those in the fruit tissues. In the sepals, $\mathrm{GA}_{1}$ plus $\mathrm{GA}_{4}$ peaked transiently while the photosynthetic system was induced, and again close to seed ripening. The sepals of unfertilized and depistillated flowers contained very low levels of bioactive GAs (Figure 4B). Level of $\mathrm{GA}_{4}$ in sepals was more affected by fruit absence than $\mathrm{GA}_{1} \cdot{ }^{26}$ In the sepals of depistillated flowers, level of catabolites $\left(\mathrm{GA}_{34}\right.$ and $\left.\mathrm{GA}_{8}\right)$ was in accordance with level of respective bioactive GAs. This finding suggests that decreased biosynthesis, rather than increased catabolism, resulted in reduced $\mathrm{GA}_{4}$ and $\mathrm{GA}_{1}$ levels.

\section{Endogenous Auxins}

Auxins are indolic compounds (Figure 2). Their biosynthesis may be accomplished by two separate paths: the tryptophan (Trp)-dependent pathway beginning with amino acid Trp, and Trp-independent pathway in which IAA can be synthesized from an indolic precursors other than Trp. ${ }^{65,66}$ Although the indole-3-acetic acid (IAA) is the most common naturally occurring auxin, other compounds such as 4-chloroindole-3-acetic acid (4-Cl-IAA) and indole-3-butyric acid (IBA) have also been identified as an endogenous auxins in some plant species. Auxins exist in plant tissue as a mixture of free (generally only 5-10 \%) and conjugated (approximately 90-95\%) forms. IAA can be ester-linked to different sugars or amide-linked to amino acids and peptides. Proposed roles of these conjugates include storage, transport, compartmentalization, protection against degradation and detoxification. ${ }^{50,66,67}$ Auxins are reported to play the instructive role in the flower ${ }^{68}$ and the fruit development, ${ }^{69}$ and participate in the coordination between floral organs. ${ }^{5}$
To assess the dynamics of auxins during flower and fruit development of the Christmas rose, endogenous auxin levels (precursor IEt, free IAA, and amide conjugates) were determined in the different tissues by LC-MS/MS (consisting of a triple-quadrupole mass spectrometer and an Acquity UPLC System) using ${ }^{15} \mathrm{~N}$ - and/or ${ }^{2} \mathrm{H}_{5}$-labeled internal standards. ${ }^{70}$

The results of profile and dynamics of auxins in perianth, fruit and flower stalk of the Christmas rose during development have been reported recently. ${ }^{27}$ Total auxin level (IAA and amid conjugates of IAA) during development are shown on Figure 3C. In the fruit, auxins start accumulating drastically during early development reaching maximum at last stage of intensive seed filling. As fruit development proceeds, amount of amidconjugates increases following the free IAA level. Approximately $98 \%$ of total fruit auxins arose in seeds. Among the conjugates identified in fruit, IAA-Asp and IAA-Glu are the most abundant. Alongside IAA aminoacid conjugates described earlier in different plant species, ${ }^{50,65}$ novel conjugates with Val, Gly, and Phe were identified in Helleborus seed for the first time in the higher plants. ${ }^{70}$ IAA-Asp and IAA-Glu are mostly considered as an irreversible catabolites. Other amid conjugates (with Ala, Leu, Gly, Phe, Val), which are good substrates for auxin amidohydrolases in vitro are suggested to participate in storage and hormone homeostasis as a slow-releasing source of free IAA ${ }^{67}$ Seeds of many species are reported as rich in amide conjugates, which are the main source of active auxins in the period of germination until young seedlings are capable to set up their own de novo auxin biosynthesis.

In the perianth, auxin level was slightly elevated during anthesis when sepals are still growing, and later, at "green stage" of post-anthesis, during the intensive photosynthetic activity and assimilate production. Depistilated sepals of the same age contain significantly less amount of total auxins (Figure 4C).

\section{Hormonal interplay during fruit development}

Morphological changes of the Christmas rose flower are obviously regulated by complex interplay of, at least, three groups of plant hormones, cytokinins, gibberellins and auxins. Endogenous hormones analyses showed that their accumulation in fruit and sepals is tightly regulated and appears during certain developmental stages. Thus, GAs, particularly $\mathrm{GA}_{4}$ is the first hormone elevated in carpels after fertilization ("Male" stage) and reached peak at early fruit development. $\mathrm{GA}_{1}$ accumulation starts later and peaked during intensive fruit growth and elongation (Figure 3). Next stage of fruit development ("Ligh green") is, in addition to further increase of $\mathrm{GA}_{4}$, also characterized by 10 fold increase of free cytokinins. "Light green" stage of development is period of embryo and endosperm differentiation and intensive cell divi- 
sions. After that, IAA starts rising during fruit growth and intensive seed filling. $\mathrm{GA}_{1}$ elevation was observed in fruit in accordance with IAA accumulation. Time scale of hormone accumulation in $H$. niger fruit is mostly in agreement with that observed for tomato fruit. ${ }^{3}$ The main difference is that IAA and cytokinins maintain high in the Christmas rose fruit until the end of development, while they decrease much earlier in tomato fruit. In hellebores fruit high level of cytokinins and auxins may be connected with immature embryo which need postripening period out of mother plant to accomplish the full development. ${ }^{24-26}$ In the sepals hormonal changes are not such a notable as observed in fruit tissue, but overall hormonal levels are significantly lower if fertilization failed (Figure 4). Thus, sepals of depistillated flowers contained approximately four times lower concentrations of cytokinins and gibberellins, and two times less auxins than fertilized counterparts. It seems that, in part, signals from developing fruit mediate plant hormone biosynthesis in sepals causing their post-anthesis morphological changes. Plant development is generally regulated by a complex interplay of different plant hormones. It is clearly documented that auxin and cytokinin act antagonistically. Auxin may regulate cytokinin metabolism and vice versa. Auxin mediates rapidly negative control of the cytokinin pool by suppressing the biosynthesis via iPMP, while the effect of cytokinins on the auxin pool in the plant is slower. ${ }^{71,72}$ Auxins are also involved in the regulation of gibberellins biosynthesis and catabolism. ${ }^{5}$ The best example is pea fruit in which auxin (particularly 4-Cl-IAA) can mimic the seeds in regulation of the GA biosynthesis and catabolic pathways in surrounding pericarp tissue enabling its growth and elongation. ${ }^{73,74}$ In case of the Christmas rose flower, further analyses are needed to elucidate a seed-derived signals and complex hormonal interplays involved in regulation of the reproductive development.

\section{CONCLUSION}

Reproductive development of the Christmas rose (Helleborus niger L.) is one of few examples of the postanthesis phenomenon in the world of flowering plants: following fertilization white perianth becomes green, photosyntheticaly active and persist during fruit development. ${ }^{17-19}$ Absence of the developing fruit causes certain inhibition of morphological changes such as sepal greening and flower stalk elongation. The profile and dynamics of three main groups of plant hormones (cytokinins, gibberellins and auxins) were investigated by LC-MS/MS in the Christmas rose floral tissues during development. Developing fruit, mostly seeds, are rich source of all three group of plant hormones which, through a complex interplay, coordinate development of other floral parts.
Acknowledgements. Research was supported by grants (currently no. 098-0982913-2829) awarded by the Croatian Ministry of Science, Education and Sports and by joint research agreements with the Republic of Slovenia. I am particularly grateful to my mentor and colleague Dr. Volker Magnus with whom I started working on Helleborus physiology. Thanks to all of my colleagues who participated in research presented by this review.

\section{REFERENCES}

1. J. A. Ozga and D. M. Reinecke, J. Plant Growth Regul. 22 (2003) 73-81.

2. P. J. Davies, Plant hormones. Biosynthesis, signal transduction, action, Dordrecht Boston London: Kluwer Academic Publishers, 2004, p. 750.

3. A. Srivastava and A. K. Handa, J. Plant Growth Regul. 24 (2005) 67-82.

4. S. Yamaguchi, Annu. Rev. Plant Biol. 59 (2008) 225-251.

5. E. Sundberg and L. Østergaard, Cold Spring Harb. Perspect. Biol. 1 (2009) 1-14.

6. S. O'Neill, Annu. Rev. Plant Physiol. Plant Mol. Biol. 48 (1997) 547-574.

7. W. G. van Doorn, J. Exp. Bot. 48 (1997), 1615-1622.

8. Y. Xu and M. R. Hanson, Plant Physiol. 122 (2000) 1323-1334.

9. H. Thomas, H. J. Ougham, C. Wagstaff, and A. D. Stead, J. Exp. Bot. 54 (2003) 1127-1132.

10. W. G. van Doorn and E. J. Woltering, Trends Plant Sci. 10 (2005) 117-122.

11. H. J. Rogers, Ann. Bot. 97 (2006) 309-315

12. M. Palandri M, Caryologia 20 (1967) 273-285.

13. H. J. Chaves das Neves and M. S. S. Pais, Biochem. Biophys. Res. Commun. 95 (1980) 1387-1392.

14. H. J. Chaves das Neves and M. S. S. Pais, Tetrahedron Letters 21 (1980) 4387-4390.

15. P. Grönegress P, J. Microscopie 19 (1974) 183-192.

16. P. Sitte, Z. Pflanzenphysiol. 73 (1974) 243-265.

17. B. Salopek-Sondi, M. Kovač, N. Ljubešić, and V. Magnus, J. Plant Physiol. 157 (2000) 357-364.

18. B. Salopek-Sondi, M. Kovač, T. Prebeg, and V. Magnus, J. Exp. Bot. 53 (2002) 1949-1957.

19. B. Salopek-Sondi and V. Magnus, Int. J. Plant Dev. Biol. 1 (2007) 151-159.

20. B. Mathew, Hellebores, Alpine Garden Society, Lye End Link, St. John's Woking, Surrey, U. K. 1989, p. 180.

21. G. Rice G and E. Strangman, The gardener's guide to growing hellebores. Portland, Oregon: Timber Press, 1993, p. 160.

22. A. Šušek, A. Ivančić, M. C. Lemoine, J. P. Guillemin, J. Caneill, M. Šiško, F. Janžeković, and L. Praprotnik, Acta Biol Cracov Ser Bot. 47 (2005) 129-135.

23. J. L. Vesprini and E. Pacini, Plant Systemat. Evol. 252 (2005) 63-70.

24. Y. Niimi, D.-S. Han, and S. Abe, Sci. Hortic. 107 (2006) 292-296.

25. P. Tarkowski, D. Tarkowska, O. Novak, S. Mihaljević, V. Magnus, and B. Salopek-Sondi, J. Exp. Bot. 57 (2006) 2237-2247.

26. B. T. Ayele, V. Magnus, S. Mihaljević, T. Prebeg, R. ČožRakovac, J. A. Ozga, D. M. Reinecke, L.N. Mander, Y. Kamiya, S. Yamaguchi, and B. Salopek-Sondi, J. Plant Growth Regul. 29 (2010) 194-209.

27. A. Brcko, A. Penčik, V. Magnus, T. Prebeg, S. Mlinarić, J. Antunović, H. Lepeduš, V. Cesar, M. Strnad, J. Rolčik, and B. Salopek-Sondi. J. Plant Growth Regul. (2011). 
28. H. Ohno and S. Kako, J. Japan Soc. Hort. Sci. 60 (1991) 159-169.

29. G. R. Hanks and A. R. Rees, New Phytol. 78 (1977) 579-591.

30. M. Saniewski and W. J. De Munk, Sci. Hortic. 15 (1981) 363-372.

31. E. Edelbluth and H. Kaldewey, Planta 131 (1976) 285-291.

32. G. Aschan and H. Pfanz, Flora 198 (2003) 81-97.

33. G. Aschan, H. Pfanz, D. Vodnik, and F. Batič, Photosynthetica 43 (2005) 55-64.

34. A. E. Antlfinger and L. F. Wendel, Am. J. Bot. 84 (1997) 769-780.

35. G. Aschan and H. Pfanz, Flora 201 (2006) 623-632.

36. T. Prebeg, N. Ljubešić, and M. Wrischer, Phyton 39 (1999) 75-78.

37. K. Werner and F. Ebel, Flora 189 (1994) 97-130.

38. C. M. Herrera, Am. J. Bot. 92 (2005) 1486-1491.

39. Y. Kanno, Y. Jikumaru, A. Hanada, E. Nambara, S. R. Abrams, Y. Kamiya, and M. Seo, Plant Cell Physiol. 51 (2010) 1988-2001.

40. S. Gan and R. M. Amasino, Science 270 (1995) 1986-1988.

41. H. A. Zavaleta-Mancera, H. Lopez-Delgado, H. Loza-Tavera, M. Mora-Herrera, C. Trevilla-Garcia, M. Vargas-Suarez, and H. Ougham, J. Plant Physiol. 164 (2007) 1572-1582.

42. N. Aharoni and A. E. Richmond, Plant Physiol. 62 (1978) 224-228.

43. I. F. Kappers, W. Jordi, F. M. Maas, G. M. Stoopen, and L. H. W. van der Plas, Physiol. Plant. 103 (1998) 91-98.

44. T. Trebitsh, E. E. Goldschmidt, and J. Riov, PNAS USA 90 (1993) 9441-9445.

45. H. J. Ougham, A. M. Thomas, B. J. Thomas, G. A. Frick, and G. A. Armstrong, J. Exp. Bot. 52 (2001) 1447-1454.

46. E. Gabryszewska and M. Saniewski, Sci. Hort. 19 (1983) 153-159.

47. P. L. Rietveld, C. Wilkinson, H. M. Franssen, P. A. Balk, L. H. W. van der Plas, P. J. Weisbeek, and D. A. de Boer, J. Exp. Bot. 51 (2000) 587-594.

48. C. M. Wolbang, P. M. Chandler, J. J. Smith, and J. J. Ross, Plant Physiol. 134 (2004) 769-776.

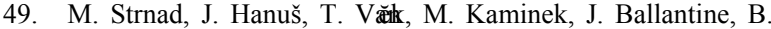
Fussell, and D. E. Hanke, Phytochemistry 45 (1997) 213-218.

50. A. Bajguz and A. Piotrowska, Phytochemistry 70 (2009) 957-969.

51. D. S. Letham, Cytokinins as phytohormones - sites of biosynthesis, translocation, and function of translocated cytokinins, in: D. S. Mok and M. C. Mok (Eds.) Cytokinins. Chemistry, activity, and function. Boca Raton: CRC Press, 1994, pp. 57-80.
52. D. H. Lewis, G. K. Burge, D. M. Schmierer, and P. E. Jameson, Physiol. Plant. 98 (1996) 179-186.

53. G. M. Banowetz, K. Ammar, and D. D. Chen, Plant Cell Environ. 22 (1999) 309-316.

54. J. Yang, J. Zhang, Z. Huang, Z. Wang, Q. Zhu, L. Liu, Ann. Bot. 90 (2002) 369-377.

55. R. J. N. Emery, L. Leport, J. E. Barton, N. C. Turner, and C. A. Atkins, Plant Physiol. 117 (1998) 1515-1523.

56. R. J. N. Emery, Q. Ma, and C. A. Atkins, Plant Physiol. 123 (2000) 1593-1604.

57. T. Rijavec, M. Kovač, A. Kladnik, P. S. Chourey, and M. Dermastia, J. Integr. Plant Biol. 51 (2009) 840-849.

58. A. P. Sagare, Y. L. Lee, T. C. Lin, C. C. Chen, and H. S. Tsay, Plant Sci. 160 (2000) 139-147.

59. Y. Tokuji and K. Kuriyama, J. Plant Physiol. 160 (2003) 133141.

60. R. P. Pharis and R. W. King, Annu. Rev. Plant Physiol. 36 (1985) 517-568.

61. M. Varbanova, S. Yamaguchi, Y. Yang, K. McKelvey, A. Hanada, R. Borochov, F. Yu, Y. Jikumaru, J. Ross, D. Cortes, C. J. Ma, J. P. Noel, L. Mander, V. Shulaev, Y. Kamiya, S. Rodermel, D. Weiss, and E. Pichersky, Plant Cell 19 (2007) 32-45.

62. S. M. Swain, J. B. Reid, and Y. Kamiya, Plant J. 12 (1997) 1329-1338.

63. M. Noma, J. Huber, D. Ernst, and R. P. Pharis, Planta 155 (1982) 369-376.

64. W. Mitsuhashi, T. Toyomasu, H. Masui, T. Katho, K. Nakaminami, Y. Kashiwagi, M. Akutsu, H. Kenmoku, T. Sassa, S. Yamaguchi, Y. Kamiya, and H. Kamada, Biosci. Biotechnol. Biochem. 67 (2003) 2438-2447.

65. A. W. Woodward and B. Bartel, Ann. Bot. 95 (2005) 707-735.

66. Y. Zhao, Annu. Rev. Plant Biol. 61 (2010) 49-64.

67. J. Ludwig-Müller, J. Exp. Bot. 62 (2011) 1757-1773.

68. Y. Cheng and Y. Zhao, J. Integr. Plant Biol. 49 (2007) 99-104.

69. D. Alabadí, M. A. Blázquez, J. Carbonell, C. Ferrándiz, and M. A. Pérez-Amador, Int. J. Dev. Biol. 53 (2009) 1597-1608.

70. A. Penčik, J. Rolčik, O. Novak, V. Magnus, P. Bartak, R. Buchtik, B. Salopek-Sondi, and M. Strnad, Talanta 80 (2009) 651-655.

71. A. Nordström, P. Tarkowski, D. Tarkowská, R. Norbaek, C. Åstot, K. Doležal, and G. Sandberg, Proc. Natl. Acad. Sci. U. S. A. 101 (2004) 8039-8044.

72. L. Moubayidin, R. Di Mambro, and S. Sabatini, Trends Plant Sci. 14 (2009) 557-562.

73. J. J. Ross, D. P. O'Neill, J. J. Smith, H. J. Kerckhoffs, and R. C. Elliott, Plant J. 21 (2000) 547-552.

74. J. O. Ozga, D. M. Reinecke, B. T. Ayele, P. Ngo, C. Nadeau, and A. D. Wickramarathna, Plant Physiol. 150 (2009) 448-462. 